Tatiana Iljuszeczkina

Nowosybirsk

\title{
Polonica w kolekcji książek europejskich syberyjskiej biblioteki akademickiej
}

Kolekcja europejskiej książki zabytkowej (XV - początki XX w.) Państwowej Publicznej Naukowo-Technicznej Biblioteki Syberyjskiego Oddziału Rosyjskiej Akademii Nauk zapoczątkowana została we wczesnych latach sześćdziesiątych i jest rówieśnicą największej za Uralem biblioteki akademickiej na Syberii. Początek dało jej kilkadziesiąt obcojęzycznych starodruków, które pierwotnie uważane były za szczególnie cenne w zasobach Oddziału Przechowywania Zbiorów. W 1967 r. zostały one przekazane do zbiorów nowo utworzonego w strukturze biblioteki Oddziału Książki Rzadkiej i Rękopisów. Obecnie liczba europejskich wydawnictw epoki ręcznej prasy (1455-1830) w zbiorach naszego oddziału dochodzi do 2 tys. jednostek magazynowych.

Stanowiąca integralną część biblioteki akademickiej kolekcja europejskich starych druków od początku była budowana z myślą o adekwatnym zobrazowaniu rozwoju światowej i europejskiej nauki, historii i kultury. Dzisiaj jest jasne, że idea ta przyniosła dobre owoce. Świadczą o tym kolekcje cymeliów w zbiorach naszego Oddziału: inkunabułów, wydawnictw naukowych (XV-XVIII w.), dokumentów z okresu Wielkiej Rewolucji Francuskiej, księgozbiór Tobolskiego Seminarium Duchownego oraz biblioteki Kopalń Koływano-Woskieriesenskich. Opiszemy krótko każdą z tych kolekcji, ponieważ stanowią one kontekst prawie półwiekowego bytowania polskich książek, które niegdyś znalazły się na Syberii.

W zbiorach biblioteki znajduje się dziewięć inkunabułów z lat 14801500. Pierwszy z nich to traktat astronomiczny Piotra z Ailly (13501420) Imago mundi (Louvain: Johann von Paderborn, 1483, 172 f., $\left.2^{\circ}\right)^{1}$. Po nim następują: dzieła Anzelma (1033-1109), arcybiskupa Canterbury (Nürnberg: Kaspar Hochfeder, 27 III 1491, 182 f., $\left.2^{\circ}\right)^{2}$; Nowy Testament

\footnotetext{
${ }^{1}$ ISTC ia00477000; GW M31954 (przyp. red.)

2 ISTC ia00759000; GW 02032 (przyp. red.)
} 
z komentarzami Mikołaja z Lyry i Wilhelma Britona (Biblia cum postillis Nicolai de Lira et expositionibus Guillelmi Britonis in omnes prologos S. Hieronymi et additionibus Pauli Burgensis replicisique Matthie Doering; Nicolaus de Lyra, Contra perfidiam Iudaeorum, Nürnberg: Anton Koberger, 12 Apr. 1493, Pars I-IV, $2^{\circ}$.) - egzemplarz pochodzący z kolekcji M. N Tichimirowa ${ }^{3}$; dekrety soboru w Bazylei wydane przez Sebastiana Branta (1457-1521) - uczonego prawnika, autora szeregu utworów dydaktycznych (Decreta Concilii Basiliensis, ed. Sebastian Brant, Basel: Jacob Wolff de Pforzham, post I III 1499, 112 f., $\left.4^{0}\right)^{4}$ i połączone w jeden klocek introligatorski z dekretami soboru w Konstancji 1414 r. (Concilium Constantiense: Acta et decreta, Hagenau: Heinrich Gran pro Johann Rynman, 11 IV 1500, 112 f. $\left.4^{\circ}\right)^{5}$ oraz z dziełem Gianfrancesca Poggia Braccioliniego (Refutatorium errorum Hieronymi Savonarolae, Leipzig: Jacob Thanner, $\left.1498,4^{\circ}\right)^{6}$; następnie prace gramatyczne Pryscjana (Priscianus, Opera, Venezia: Michael Manzolus, 15 XII 1481, 326 f., $\left.2^{\circ}\right)^{7}$, pierwsza część dzieła Panteologia Reineriusa de Pisis (Reinerius de Pisis,Pantheologia sive summa universae theologiae, Venezia: Hermann Liechtenstein, 12 IX 1486, 308 f., $\left.2^{\circ}\right)^{8}$ oraz dzieło piętnastowiecznego włoskiego dramaturga Carla Verardiego (Verardus Carolus, In laudem Serenissimi Ferdinandi Hispaniarum regis, Bethice et regni granatae, obsidio, victoria et triumphus, $\left.4^{\circ}\right)^{9}$. Informacje na temat tych wydawnictw zbiera krótki drukowany przewodnik po inkunabułach w zbiorach GPNTB SO RAN ${ }^{10}$.

Najliczniejsza jest kolekcja europejskiej książki naukowej od XV do początku XX w. Myśl naukową zachodniej Europy reprezentują w niej książki z zakresu nauk przyrodniczych, matematyki, fizyki, medycyny, filozofii, chemii, teologii, alchemii, astronomii, historii i geografii. Sa to wydania dzieł filozofów Franciszka Bacona, Kartezjusza, Johannesa Clauberga, Henriego Leroy (Regiusa), Antoine'a Legranda i Johanna Jakoba Waldschmidta, dzieła medyczne Garioponta, Johannesa Mesue'a, Apponiusa, Galena, Andreasa Vesaliusa, Ambroise'a Paré, Paracelsusa, oprócz tego prace z zakresu medycyny napisane przez ich zwolenników lub przeciwników: Franciscusa Valleriolę, Antonia Musę Brasavolę, Leonharta

3 ISTC ib00618000; GW 04293 (przyp. red.)

4 ISTC ic00799000; GW 07284 (przyp. red.)

5 ISTC ic00800000; GW 07287 (przyp. red.) ISTC ; GW (przyp. red.)

6 ISTC ip00877800; GW M34625 (przyp. red.)

ISTC ip00966000; GW M35395 (przyp. red.)

8 ISTC ir00010000; GW M36944 (przyp. red.)

9 Katalogi wyliczają kilka wydań tego inkunabułu (przyp. red.)

10 Л. М. Макарова, Инкунабуль сектора редких книг и рукописей ГПНТБ СО АН СССР, [w:] Вопросы истории книжной культуры, Новосибирск 1975, s. 166-172. 
Fuchsa, Hieronymusa Fabriciusa ab Aquapendente, Thomasa Bartholina, Daniela Sennerta, Friedricha Hoffmanna, Thomasa Sydenhama, traktaty alchemiczne i chemiczne Rajmunda Lulla, Lazarusa Erckera, Giambattisty della Porta, Johanna Rudolfa Glaubera, Johannesa Kunckela, Antonia Neriego, Ottona von Guericke, prace fizyków Roberta Boyle'a, Giovanniego Alfonsa Borelliego, Christiaana Huygensa, Johanna Christopha Sturma, Balthasara Cellariusa, dzieła astronomiczne Johannesa de Sacrobosco, Piotra d'Ailly, Georga Peurbacha, Thomasa Fienusa, Jana Heweliusza, Nicolasa Biona i wielu innych autorów, którzy w swoich czasach znacznie przyczynili się do rozwoju różnych dziedzin nauki.

W skłąd omawianej kolekcji wchodzą także obcojęzyczne książki zawierające informacje historyczne i geograficzne dotyczące Rosji i Syberii od XVII do początków XX wieku (tzw. „rossica” i „sibirica”). Znajdziemy tu prace najsłynniejszych autorów tego gatunku: Antonia Possevina, Olafa Mag-nusa, Aleksandra Gwagnina, Siegmunda von Herbersteina, Adama Oleariusa, Marcusa Zueriusa van Boxhorna, Augustina Meyerberga, Conrada van Klenk, Johana-Georga Korba, Jana Jansena Struysa. Równie interesujące są późniejsze książki poświęcone tematyce historycznej i geograficznej. W szczególności godne uwagi są wydania z XIX i początku XX w., które wpłynęły do biblioteki w latach osiemdziesiątych XX w. i posiadają na odwrocie przedniej okładziny oprawy ekslibris: „Ex libris apud || J. S. G. Simmons || Oxoniæ hospitantibus". Ekslibris ten przynależy do angielskiego slawisty, historyka ksiązki i bibliografa Johna Simona Gabriela Simmonsa (1915-2005) ${ }^{11}$. John Simmons podarował Oddziałowi Książki Rzadkiej i Rękopisów GPNTB SO RAN niewielką próbkę wydań dzieł cudzoziemskich podróżników, pisarzy i uczonych dotyczących Syberii - jej krajobrazów, flory i fauny, niektórych aspektów historii tej części Rosji. Wśród autorów książek z kolekcji Johna Simmonsa znajdujemy między innymi nazwiska George'a Kennana (1845-1924), Harry'ego de Windta (1856-1933), Henry'ego Lansdella (1841-1919), Samuela Turnera (1869-1929), Henry'ego Seebohma (1832-1895).

Unikalną częścią kolekcji zabytkowej książki europejskiej GPNTB SO RAN stanowi zbiór dokumentów z okresu Wielkiej Rewolucji Francuskiej z końca XVIII w. Druki te zostały wydane bezpośrednio podczas wydarzeń rewolucyjnych i reprezentują materiały dotyczące działalności Konstytuanty z lat 1789-1791. Jest to 400 broszur zebranych w osiemnaście klocków introligatorskich. Przechowywana w Nowosybirsku ko-

11 Е. Л. Немировский, Джон Симон Габриель Симмонс. Памяти книговеда, слависта и вообще хорошего человека, [w:] Книга. Исследования и материаль, Сб. 84, Москва 2005, s. 294-324. 
lekcja druków związanych z historią Francji nie jest jedyną w kraju, ale stanowi jeden z najpełniejszych zbiorów w Rosji.

Szczególne znaczenie dla kolekcji europejskich starodruków oraz dla zobrazowania rozwoju światowej i europejskiej nauki, historii i kultury mają księgozbiory dwóch bibliotek, które powstały na Syberii w pierwszej połowie XVIII w. Mamy tu na myśli przede wszystkim kolekcję książek Tobolskiego Seminarium Duchownego - pierwszej szkoły duchownej na Syberii, aż do roku 1801 jedynej za Uralem. Przynależność książek do Głównej Biblioteki tej placówki edukacyjnej określić można po zachowanych dawnych sygnaturach i charakterystycznych zapiskach («Изъ книгъ Тобольской Семинарской Библиотеки», «Ex libris Bibliotheca Seminarii Toboliensis») oraz specjalnej nalepce («ТОБОЛ. СЕМИН. ФУНДАМ. БИБЛИОТЕКИ. ॥ Разрядъ || № отделения ॥ Шкафъ || Полка»).

Pod koniec XVIII w. i na początku XIX w. Główna Biblioteka Seminarium zapewniała pełny dostęp do literatury koniecznej w procesie dydaktycznym oraz, na dość dobrym poziomie, dostęp do książek o charakterze ogólnokształcącym przeznaczonych do lektury pozaszkolnej i niezwiązanej z przynależnością do stanu duchownego. Kwestią regularnego gromadzenia koniecznej literatury naukowej dla biblioteki - finansowaniem, zakupem, dostarczeniem - zajmowali się metropolici, którzy stali na czele seminarium: Filoteusz (Leszczyński) (1702-1711; 1715-1721) $)^{12}$, Jan (Maksymowicz) (1711-1715), Antoni (Stachowskij) (1721-1740), Antoni (Narożnicki) (1742-1748), Antoni (Znamienskij), arcybiskup tobolski i syberyjski Atanazy (Protopopow), biskup tobolski Włodzimierz oraz archimandryta Ewfimij i wielu innych. W większości byli oni absolwentami Akademii Mohylańskiej w Kijowie, do Tobolska przyjeżdżali wraz ze swoimi dużymi bibliotekami prywatnymi, bogaci już w doświadczenie duszpasterskie w ławrach - Pieczerskiej w Kijowie, Św. Trójcy i Św. Sergiusza oraz w klasztorach diecezji czernihowskiej. Właśnie oni podarowali, ofiarowali lub zapisali w testamencie swoje prywatne księgozbiory bibliotece seminarium, o czym świadczą liczne napisy proweniencyjne, np.: „Podarowana przez rektora, archimandrytę Ewfimija".

Specjalną „syberyjską” kolekcję naszego zbioru europejskich cymeliów stanowią obcojęzyczne książki z biblioteki Kopalń Koływano-Woskriesienskich. Kopalnie, założone na Ałtaju w 1726 r. przez Akifima Nikiticza Demidowa (1678-1745), do połowy XVIII stulecia stały się

\footnotetext{
${ }^{12} \mathrm{~W}$ nawiasach podano daty pełnienia funkcji ordynariusza diecezji tobolskiej.
} 
całym kompleksem przedsiębiorstw wydobywczo-przetwórczych, posiadały Górniczą Kancelarię w Barnaule oraz mennicę. Terytorium ich działalności były dzisiejsze obwody nowosybirski i kemerowski oraz kraje krasnojarski i ałtajski.

Biblioteka Kopalń Koływano-Woskriesienskich powstawała z prywatnych księgozbiorów kadry zarządzającej, a także ze zbiorów fabrycznych i kopalnianych, które w początkach XIX w. połączone zostały w Barnaulską Bibliotekę Służbową. Na zbiory składała się literatura dydaktyczna przeznaczona dla szkół przy fabrykach oraz literatura specjalistyczna z zakresu techniki górniczej i pokrewnych dziedzin nauki. Na kartach tytułowych przechowywanych w GPNTB SO RAN książek, pochodzących z tej niewielkiej kolekcji znajdujemy następujące nazwiska autorów i thumaczy: Christlieb Ehregott Gellert (1713-1795), Abraham Gotthelf Kästner (1719-1800), Wenceslaus Johann Gustav Karsten (1732-1787), Richard Kirwan (1733-1812), Lorenz Fridrich von Crell (1745-1816), Johann Kunkel (1630-1702), Franz Ludwig von Cancrin (1738-1816), Johann George Lehmann (1765-1811) oraz innych. Na przynależność książek, zarówno obcych, jak i rosyjskich, do bibliotek fabrycznych wskazuje kilka charakterystycznych cech zewnętrznych. Jedną z nich stanowi brązowy stempel w kształcie okręgu z majuskulnymi literami „KWZ” na jasnym tle. Inna charakterystyczną cechą jest zakreślanie na dowolnie wybranej stronie, w różnych słowach drukowanego tekstu, pewnych liter, które razem można odczytać jako «Cronsbuch», «ein Cronsbuch», «Kronsbuch», «ein Kronsbuch», co oznacza „książka skarbowa”.

Biblioteka Kopalń Koływano-Woskriesienskich jest pierwszą biblioteką naukowo-techniczną na Syberii, w której zebrano najbardziej aktualne w owych czasach prace zagranicznych uczonych dotyczące przemysłu górniczo-wydobywczego.

Tak w najbardziej ogólnym zarysie przedstawia się zbiór europejskich książek Oddziału Książki Rzadkiej i Rękopisów GPNTB SO RAN w Nowosybirsku ${ }^{13}$. Źródła wpływu zagranicznych książek do naszych zbiorów zgodnie z naszą wiedzą są w zasadzie typowe zarówno dla dużych bibliotek rosyjskich, jak i dla zagranicznych: dary; zakup całych bibliotek prywatnych; zakup od osób prywatnych pojedynczych egzemplarzy; przejmowanie z innych bibliotek zagranicznych książek jako niezgodnych z profilem ich gromadzenia; wymiana z innymi bibliotekami itd. Odnośnie do historii kolekcji, które wchodzą w skład naszych zbiorów, to jest ona zróżnicowa-

13 Więcej na ten temat zob. T. Н. Илюшечкина, Собрание западноевропейских книг XV-начала XIX в. отдела редких книг и рукописей ГПНТБ СО РАН: вчера, сегодня, завтра, „Библиосфера”, 2010, nr 3, s. 87-97. 
na: jedne tworzyły się stopniowo w naszych zbiorach, inne weszły już jako ukształtowane całości; jedne pochodzą z centralnych regionów kraju, inne mają pochodzenie syberyjskie. W szczególności druki z czasów Wielkiej Rewolucji Francuskiej otrzymaliśmy z rąk jednego z moskiewskich kolekcjonerów w charakterze zebranej prywatnej kolekcji. Podobnie zasadnicza część europejskich wydań naukowych, które stały się podstawą naszej największej kolekcji, wpłynęła ze stołecznych bibliotek, z ich zasobów przeznaczonych na wymianę, podczas gdy zagraniczne książki należące do Tobolskiego Seminarium Duchownego i Kopalń Koływano-Woskieresienskich stanowią fragment zbiorów bibliotek syberyjskich ukształtowanych jeszcze w XVIII w. i zachowanych do naszych dni.

W takim kontekście w zbiorach Oddziału Książki Rzadkiej i Rękopisów GPNTB SO RAN bytują książki, które w ten czy inny sposób związane są z historią Polski. Mamy tu na myśli książki wydane po polsku lub w Polsce, są to też prace o Polsce lub Polakach, a także cymelia pochodzące z najstarszych polskich bibliotek, które na skutek różnorodnych wypadków znalazły się na Syberii. Polskie książki nie tworzą osobnego działu w ramach zbiorów zagranicznych Oddziału Książki Rzadkiej i Rękopisów. Co więcej, znajdują się one tylko w dwóch kolekcjach należących do naszego Oddziału: kolekcji książek Tobolskiego Seminarium Duchownego oraz kolekcji europejskich książek naukowych XV-XX w.

Wyżej powiedziane zostało, że jedna z pierwszych syberyjskich bibliotek - Główna Biblioteka Tobolskiego Seminarium Duchownego w przeważającej mierze składa się z prywatnych księgozbiorów metropolitów tobolskich. Wśród reprezentowanych w tobolskiej kolekcji GPNTB SO RAN europejskich ośrodków wydawniczych przeważają niemieckie. Z punktu widzenia różnorodności językowej przeważają książki po łacinie, po grecku, w języku niemieckim, francuskim i polskim. Co się tyczy książek po polsku oraz książek drukowanych w polskich oficynach od XVII do XIX w., to reprezentowane są one dość skapo w kolekcji tobolskiej. Sa to pojedyncze egzemplarze książek wydane w Krakowie: P. Owidivsza Nasona Metamorphoseon, to iest Przeobrażenia, kśiag piętnaśćie, przektádánia Iakvba Zebrowskiego ${ }^{14}$ (w Krakowie, w drukárni Fránćißká Cezárego, Roku Páńskiego, 1636); Słonecznik albo porownanie woli ludzkiey z wola Boza ktore piaćia kśiag lacńskim ięzykiem opisat W. Ociec Ieremiasz Drexelivs ${ }^{15}$ Soc[ietatis] Iesv, a ná polska mowe przettumáczyt y do druku podat Vrbanvs Vallistius de Stari Las (w Kra-

\footnotetext{
${ }^{14}$ Jakub Żebrowski (zm. 1636).

15 Jeremias Drexel SJ (1581-1638).
} 
kowie, w drukárni Lvkasza Kvpisza, I. K. M. Typ[ografa], Roku P. 1649). W Warszawie wytłoczono pozycję: Arytmetyka Podtug regut JMc Pana Beniamina Hederichsa ${ }^{16}$ Rektora Skót Hayn gruntowna drogę toruiaca do matematycznych umieiętności przydatkami innych Autorow powiększona z niemieckiego języka na polski dla młodzy szkolney wydrukowana. Za pozwoleniem Zwierzchności (w Warszawie, nakładem Michała Groella, J. K. M. Komissarza i Bibliopoli, w Marywilu N. 19. pod znakiem Pòétow 1774). W Berdyczowie wydrukowany został Wykład nauk i sposobu tychze dawania w Gimnazyum Podolskiem przez Nauczycielów w tymże Gymhazyium ułożony a ku powszechney Pr. Obywatelów gubernii Podolskiey wiadomości przez dyrektora tegoż Gymnazyium i szkót Podolskich X. Michała Maciejowskiego Kan. Kat. Kamienieckiego, do druku podany (1816, Drukowano w Berdyczowie u XX. Karmelitów). Zachowała się także książka wydrukowana w Poczajowie - Apteka domowa dla poratowania zdrowia potrzebna z autorów różnych zebrana, tak też lekarstwa dla koni, bydta i innego drobiu, z przydatkiem ciekawych wiadomości, za pozwoleniem zwierzchności do druku podana (w Poczajowie w drukarni J. K. Mci. u WW. OO. Bazylianów, 1788). W Poczajowie, jak wiadomo, prowadzona była aktywna działalność wydawnicza nie tylko w języku ukraińskim, ale i w polskim oraz po łacinie. Obok dzieł autorskich drukowano także podręczniki szkolne. Jedno wydanie po łacinie pochodzi ze środowiska polskiego we Wrocławiu: Barlaam Hieromonachus ${ }^{17}$, Institvtionvm lingvae graecae liber, vtilissimis regvlis, cvm aliis ad solidiorem hvivs sacri idiomatis cognitionem observationibvs, non solvm ad rectam vocvm $\Sigma Y N \Theta E \Sigma I N$, sed etiam ad conficiendvm metrvm graecvm pernecessariis, ex variis avctoribvs collectis, indicibvsqve graeco et latino instrvctvs et exhibitvs in Academia Kijowomohytozaborowsciana, nvnc primvm typis evvlgatvs (Wratislaviae, apvd Iohannem Iacobvm Korn, 1746).

Tematyka wydań pochodzenia polskiego, jak to wynika z kart tytułowych, jest dość różnorodna. Oprócz podręcznika do nauki greki w kolekcji znajduje się podręcznik do arytmetyki, prace teologiczne i medyczne, poemat Metamorfozy starożytnego poety rzymskiego Owidiusza w thumaczeniu Jakuba Żebrowskiego, opracowanie metodyczne dla nauczycieli o prawidłowym organizowaniu lekcji z różnych przedmiotów i dla różnych poziomów (klas) nauczania. Karty tytułowe części polskich podręczników, podobnie jak i pozostałych europejskich publikacji spośród

\footnotetext{
16 Benjamin Hederich (1675-1748).

${ }^{17}$ Bazyli Łaszczewski, imię zakonne Barlaam (1702-1774).
} 
obcojęzycznej części biblioteki seminarium duchownego, posiadają wskazanie na przeznaczenie wydawnictwa do użytku szkolnego, np. ,dla młodzi szkolney wydrukowana" (Arytmetyka). Odnośnie do czasu wydania tych książek, to dwie spośród nich datowane są na pierwszą połowę XVII w., oprócz nich są także wydania datowane od połowy XVIII do pierwszej ćwierci XIX w.

Kolekcja książek zagranicznych reprezentująca w GPNTB SO RAN bogaty niegdyś księgozbiór Głównej Biblioteki Tobolskiego Seminarium Duchownego pozwala nam stwierdzić, że od chwili swojego powstania na Syberii w pierwszej połowie XVIII w. przez wszystkie lata swojego istnienia zapewniała ona niezbędną literaturę dla pełnego procesu dydaktycznego. Z tego powodu uzupełniano jej księgozbiór nie tylko literaturą ojczysta, lecz także produkcją wydawniczą różnych ośrodków europejskich, w tej liczbie i polskich. Niemniej przechowywana w Oddziale Książki Rzadkiej i Rękopisów kolekcja książek Tobolskiego Seminarium Duchownego stanowi tylko małą cząstkę Głównej Biblioteki Seminarium. Skala kolekcji, niestety, nie daje pełnego wyobrażenia o tym, w jakiej proporcji gromadziła ona polskie wydania w stosunku do innych europejskich. Jednocześnie nawet na podstawie pojedynczych polskich wydawnictw można stwierdzić, że znajdowały się tam polskie książki oraz że odpowiadały one w pełni profilowi biblioteki seminaryjnej i razem z innymi zagranicznymi były wykorzystywane w edukacji.

Nieporównanie bardziej różnorodne materiały polskie zawiera kolekcja tak zwanych wydawnictw naukowych od XV do początku XX w. Tutaj mamy próbkę zarówno języka polskiego w starodrukach, jak i produkcji polskich ośrodków drukarstwa, a także materiały dotyczące historii Polski i Polaków. Zbadanie szeregu egzemplarzy z tej kolekcji, oprócz wiadomości o dziele, jego autorze i tematyce, prowadzi nas do badań proweniencyjnych - historii kolekcjonowania, którą odczytać można z zachowanych ekslibrisów, pieczątek, naklejek, charakterystycznych form oprawy itd. Polskie znaki własnościowe, świadczące o dawnej przynależności tego lub innego egzemplarza do jakiegoś państwowego lub prywatnego księgozbioru, spotykamy na książkach z naszych zbiorów na pojedynczych egzemplarzach lub powtarzają się one na kilku pozycjach.

Zatrzymajmy się najpierw przy znakach własnościowych zachowanych tylko na pojedynczych egzemplarzach. Dobrym przykładem takiego wydania jest książka wybitnego działacza epoki, pisarza, historyka, teologa, poety, thumacza, heraldyka i rytownika Tomasza Tretera (15471610). Krakowskie wydanie z 1685 roku biografii biskupów warmińskich tego autora (Thomae Treteri custodis canonici Varmiensis De episcopa- 
tu et episcopis ecclesiae Varmiensis, Cracoviae 1685) ma zachowane na stronach bloku książki oraz na okładzinach oprawy jednocześnie trzy interesujące znaki własnościowe: ekslibris i pieczęć biblioteki Stanisława Krzyżanowskiego oraz etykietę antykwariatu Hieronima Wildera (18761941) - polskiego historyka sztuki, bibliofila i znanego antykwariusza.

Ekslibris ten jest fragmentem białej karty $(143 \times 115$ $\mathrm{mm})$, w którego centrum w podwójnej konturowej ramce $(100 \times 70 \mathrm{~mm})$ umieszczona została kompozycja znaku własnościowego ze wskazaniem na przynależność książki: „EX LIBRIS \|| Stanislai
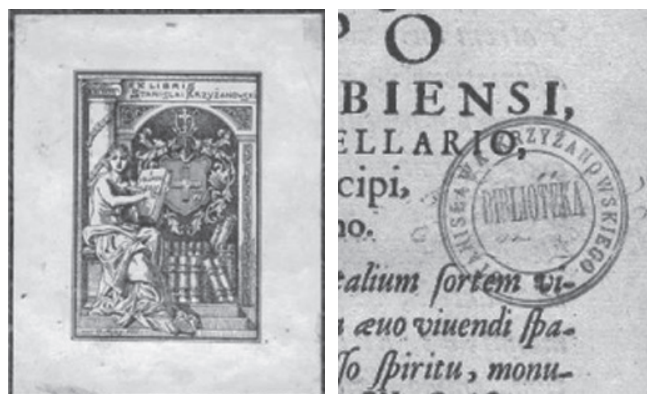
Krzyżanowski". W lewym dolnym rogu ekslibrisu widoczny jest tekst odbity typograficznie: „inv. O. May. 1911”, który najwidoczniej trzeba rozumieć jako wskazanie autora tego wyobrażenia (,inv.” oznacza ,,inventor" - rysownik, autor). Ekslibris tradycyjnie znajduje się na odwrocie przedniej okładziny.

Drugim znakiem jest pieczęć okragła ciemnoniebieskiego koloru. W centrum wewnętrznego okręgu (o średnicy $20 \mathrm{~mm}$ ) znajduje się nazwa rodzaju zbioru, a między wewnętrznym i zewnętrznym okręgiem podwójnego konturu (o średnicy

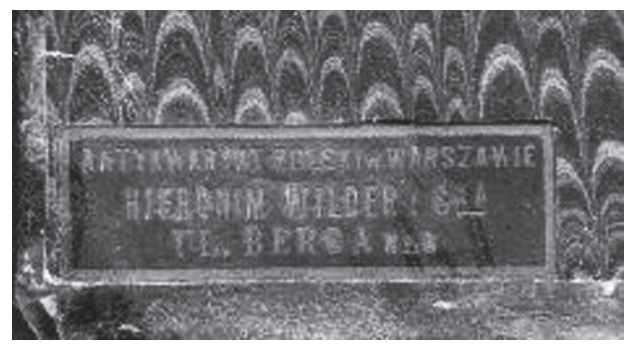
$32 \mathrm{~mm}$ ) - imię właściciela: „BIBLIOTEKA || [floratura] || STANISŁAWA KRZYŻANOWSKIEGO”. Pieczęć jest odbita na pierwszej stronie tekstu dzieła. Odbito ją na środku prawego marginesu strony, prawdopodobnie nieprzypadkowo, ponieważ znajduje się na miejscu wyskrobanej zapiski, której odczytanie okazało się niemożliwe.

Szczególnie interesująca jest prostokatna etykieta $(10 \times 35 \mathrm{~mm})$ : „ANTYKWARIAT POLSKI W Warszawie \| Hieronim Wilder i S-ka \| ul. Berga nr 8". Wykonana jest z papieru koloru czarnego, tłoczona zaś ramka i tekst - koloru czerwonego. Umieszczono ją na odwrocie przedniej okładziny, w lewym dolnym rogu.

$\mathrm{Na}$ dolnym marginesie karty tytułowej książki Tomasza Tretera, z prawej strony, znajduje się jeszcze jeden znak. Jest to czarny odcisk numeratora „14048”, podobny do porządkowego numeru egzemplarza 

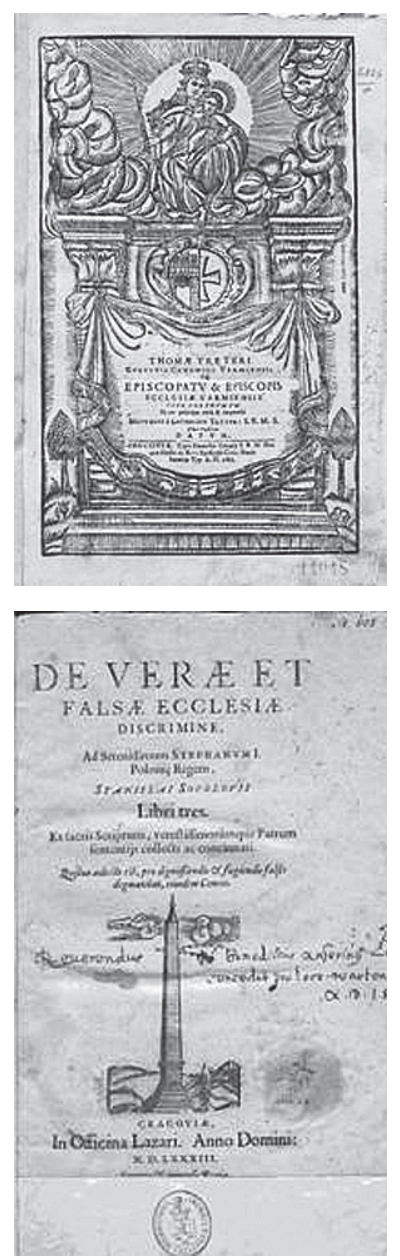

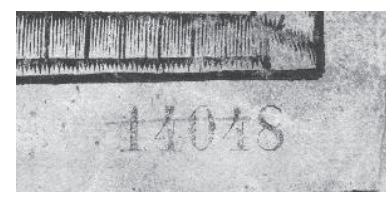

w kolekcji Stanisława Krzyżanowskiego lub antykwariatu Hieronima Wildera.

Wyjaśnienie pochodzenia tego numeru w chwili obecnej nie wydaje się możliwe, ponieważ nie jest znany kontekst, czyli inne wydawnictwa ze zidentyfikowanych księgozbiorów jako materiał porównawczy.

Następnym zidentyfikowanym znakiem własnościowym jest odbita ciemnoniebieską stemplową farbą pionowa owalna pieczęć $(30 \times 27 \mathrm{~mm}) \mathrm{z}$ tarczą herbową w centrum, dookoła której biegnie napis: „KSIĘGOZBIÓR CELIŃSKICH Z CEKOWA".

W kolekcji europejskich zabytków od XV do początku XIX wieku owa pieczęć znajduje się na krakowskim wydaniu Stanisława Sokołowskiego (1536-1593). De verae et falsae ecclesiae discrimine ad serenissimum Stephanum I. Poloniae regem z 1583 roku. Odcisk pieczęci znajduje się pośrodku dolnego marginesu chałupniczo zakonserwowanej karty tytułowej oraz na ostatniej stronie bloku książki. Książka ta należy do kolekcji rękopisów i starych druków M. N. Tichomirowa.

Następna książka, o której należy wspomnieć, to unikalne krakowskie wydanie Kronika Sarmacyey Europskiey z 1611 r. autorstwa Aleksandra Gwagnina (1534-1614). Jest to również unikat z uwagi na proweniencję - pochodzi z biblioteki Jana Fryderyka Sapiehy (1680-1751), kanclerza
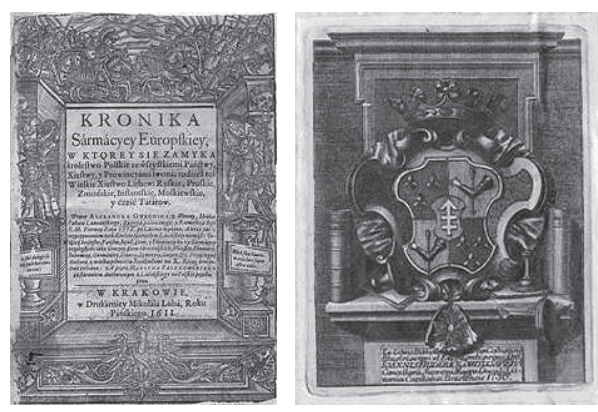
litewskiego od roku 1735, znanego posiadacza bogatego księgozbioru. Pochodzenie książki zaświadcza ekslibris, który w centrum kompozycji ma herb w barokowym kartuszu zwieńczonym koroną.

Całość kompozycji ekslibrisu przedstawia herb umieszczony 
między dwoma woluminami, pieczęciami państwowymi i dokumentami, nad tablica z napisem: „Ex Libris Bibliotecae Codnensis || Illustrissimi et Excellentissimi D[omi]ni \|| IoANNIs Friderici Comitis SAPIEHA \| Cancellarii Supremi Magni Ducat[us] Lit $=\|$ vaniae Capitanei Brestensis 1736." Możliwe jest, że format folio książki Aleksandra Gwagnina uwarunkował również rozmiar znaku własnościowego Jana Fryderyka Sapiehy. Prostokątna karta papieru z ekslibrisem mierzy $16 \times 125 \mathrm{~mm}$, odbicie zaś płyty z kompozycją ekslibrisu $-150 \times 116 \mathrm{~mm}$. Znak własnościowy zajmuje centralne miejsce na odwrocie przedniej okładziny.

Kolejnym polskim znakiem własnościowym, który udało się zidentyfikować, jest pieczęć $\mathrm{w}$ formie prostokąta $\mathrm{z}$ zaokraglonymi krótszymi bokami zawierająca tekst: „Z Ksiągo-zbioru || B. Jabłońskiego i Syna”.

Odcisk pieczęci jest koloru czarnego, tekst wewnątrz ramki złożono kursywą. W obecnej chwili na kartach europejskich wydań strarodrucznych należących do Oddziału Książki Rzadkiej i Rękopisów zidentyfikowany został tylko jeden taki znak. Znajduje się on na karcie tytułowej, po prawej stronie adresu wydawniczego, trzeciego tomu słownika polsko-łacińsko-greckiego wydanego w 1632 r. przez polskiego leksykografa Grzegorza Knapskiego (1564-1638).

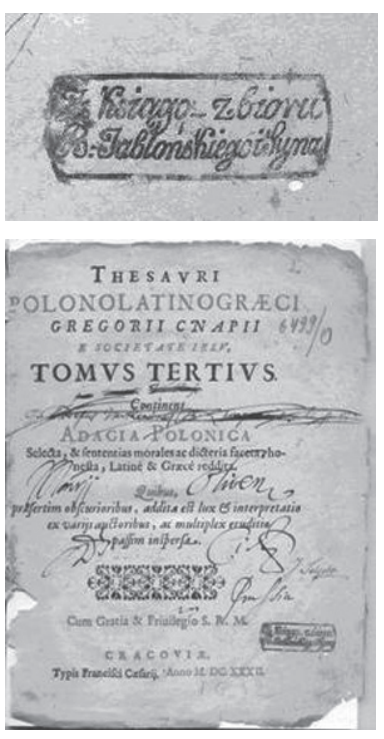

Kolejnym polskim znakiem proweniencyjnym, który omówimy w tym artykule, jest owalna pieczęć koloru ciemnoczerwonego zawierająca tekst: „DUPLIKAT || BIBLIOTEKI || PUŁAWSK[IEJ]”. Znajduje się na gdańskim wydaniu z 1652 r. dzieła autorstwa Joachima Pastoriusa (1611-1682) Bellum Scythico-Cosacicum Seu De Coniuratione Tartarorum, Cosacorum \& plebis Russicae contra Regnum Poloniae ab Invictissimo Poloniae \& Sueciae Rege Joanne Casimiro profligata, Narratio Plenioris Historiae operi praemissa. Horyzontalny owal pieczęci odbity został centralnie na odwrocie karty tytułowej książki.

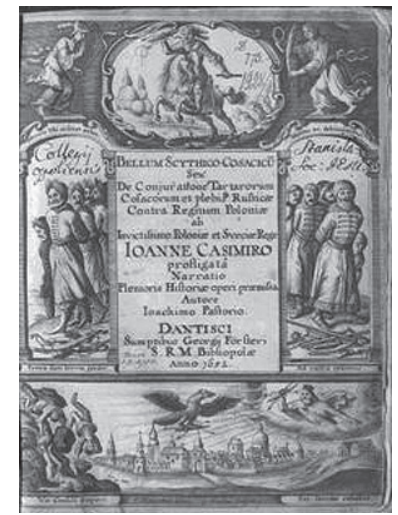


Nazwa geograficzna występująca w tekście pieczęci, świadczy o tym, że mowa jest o mieście Puławy, które od lat trzydziestych XVIII w. znalazło się w posiadaniu książąt Czartoryskich i stało się jedną z ich rezydencji. Jak wiadomo, miejscowość rozsławiona została przez jedno z największych we wschodniej Europie założeń parkowo-pałacowych, ufundowanych przez książąt Czartoryskich w duchu klasycystycznym na przełomie XVIII i XIX w., a także przez pierwsze polskie muzeum narodowe, powstałe staraniem księżny Izabeli, żony księcia Adama Kazimierza (1734-1823). Wiadomo także, że książęta Czartoryscy posiadali niezwykle bogatą bibliotekę, której początki sięgają XVII w. Dublet z pieczęcią puławskiej biblioteki pochodzi z tego księgozbioru.

Omówiliśmy wyżej unikalne, tj. występujące tylko raz w naszych zbiorach, znaki własnościowe, które świadczą o związkach książek należących do księgozbioru starych druków GPNTB SO RAN z tematyką polską - historia prywatnych bibliotek lub księgarstwa. Nazwiska polskich autorów, zagadnienia poruszane przez ich dzieła, publikacja po polsku świadczą o przynależności do historii polskiej książki. Podkreślmy, iż pewne inne jeszcze znaki własnościowe polskiego pochodzenia spotykamy na zagranicznych starych drukach GPNTB SO RAN częściej niż na jednym egzemplarzu. Te powtarzające się cechy proweniencyjne pozwalają mówić już nie tylko o pojedynczych egzemplarzach polskich cymeliów, ale o większych lub mniejszych kolekcjach polskich książek w zbiorach Oddziału Książki Rzadkiej i Rękopisów.

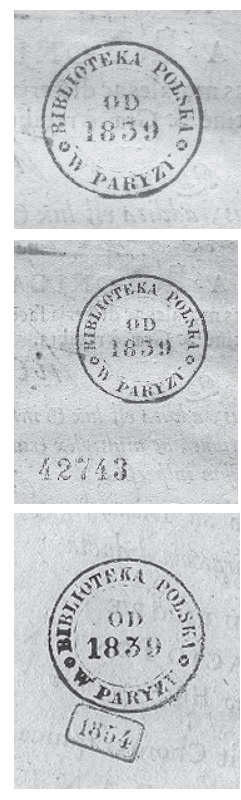

Za charakterystyczny przykład takiej kolekcji można uważać cztery foliały datowane na okres od połowy XVI do lat trzydziestych XVII w., pochodzace z zbiorów najbogatszej polskiej biblioteki poza granicami kraju - Polskiej Biblioteki w Paryżu. Została ona założona w 1838 r. przez Adama Jerzego Czartoryskiego (17701861), otworzona uroczyście w 1839 r. Syn księcia Adama Kazimierza Czartoryskiego i Izabeli z Flemingów niegdyś należał do ścisłego kręgu współpracowników młodego cesarza Aleksandra I i pełnił funkcję ministra spraw zagranicznych Cesarstwa Rosyjskiego w latach 1804-1806. Adam Jerzy Czartoryski był nie tylko założycielem biblioteki, lecz także przewodniczącym jej rady bibliotecznej. O przynależności książek do księgozbioru tej biblioteki świadczy następująca pieczęć: ,„[floratura] BIBLIOTEKA POLSKA [floratura] || W PARYZU || OD || 1839 |"”. 
Pieczęć jest koloru czarnego, okragła (średnica okręgu zewnętrznego $-30 \mathrm{~mm}$, wewnętrznego $-20 \mathrm{~mm}$ ). W pewnym odstępie od odcisku pieczęci na książkach znajduje się wykonany takim samym czarnym tuszem odcisk numeratora (pięcio- lub sześciocyfrowy): 40314, 41174, 41177, 42743. Na egzemplarzach należących do Oddziału Książki Rzadkiej i Rękopisów oba odciski (pieczęć i numer) znajdują się na odwrocie kart tytułowych. W jednym przypadku okragła pieczęć paryskiego zbioru polskich cymeliów oprócz czarnego numeru uzupełniona jest niedużą prostokątną pieczątką koloru ciemnoniebieskiego „1854” $(14 \times 8 \mathrm{~mm})$, która prawdopodobnie świadczy o dacie wpływu książki do zbiorów lub o inwentaryzacji jej zasobów w $1854 \mathrm{r}$.

Książki syberyjskiej kolekcji oznaczone następującą pieczęcią: ,„ffloratura] BIBLIOTEKA POLSKA [floratura] || W PARYZU || OD || 1839||" nie są liczne. Należą do nich dwa tomy dzieł Erazma z Rotterdamu (14691536) bazylejskiego wydania z 1540 r. (Des. Erasmi rot. Opervm Secvndvs Tomvs Adagiorvm chiliades quatvor cvm sesqvicentvria complectens, ex postrema ipsius autoris recognitione accuratissima, quibus non est quòd quicquam imposterum uereare accessurum, Basileae, ex officina Frobeniana, an. M. D. XL [1540]; Des. Erasmi rot. Opervm qvintvs tomvs qvae ad pietatem institvvnt complectitvr, quorum elenchum uersa pagina exhibet, Basileae, ex officina Frobeniana, M D XL [1540]); amsterdamskie wydanie z $1631 \mathrm{r}$. historii państwa duńskiego nadwornego historyka Johana Isaaca Pontano (1571-1639) («Rerum Danicarum historia, libris $X$ uno$q$ [ue] tomo ad domum usq[ue] Oldenburgicam deducta, authore Ioh. Isacio Pontano regio historiographo, accedit Chorographica regni Danice tractusq[ue] eius universi borealis urbiumq[ue] descriptio eodem authore cum indicibus locupletissimis, Amstelodami, Sumptibus Ioannis Ianßonii, anno 1631») oraz wspomniany wyżej ostatni tom słownika z 1632 r. polskiego leksykografa Grzegorza Knapskiego.

Podkreślmy, że na bazylejskich foliałach oprócz omawianych pieczęci zachowały się drukowane naklejki potwierdzające pochodzenie tych woluminów z Biblioteki Polskiej w Paryżu.
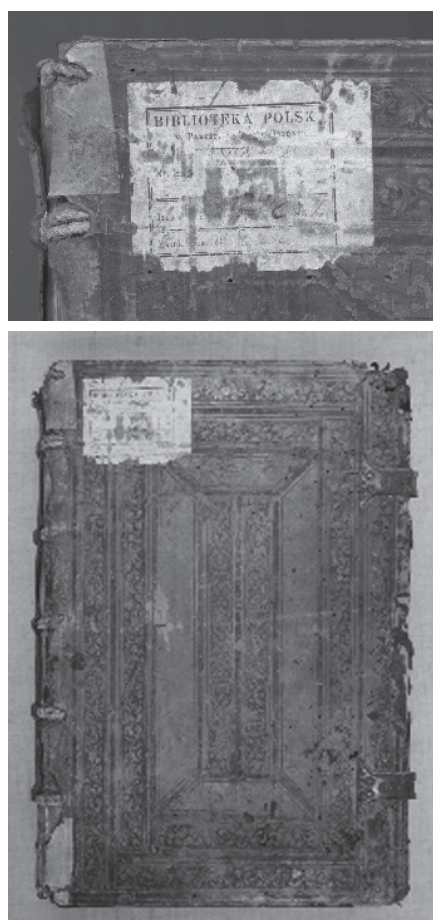
Naklejki te (format papieru $54 \times 68 \mathrm{~mm}$, rozmiar zewnętrznej ramki typograficznej $42 \times 52 \mathrm{~mm}$ ) sa w złym stanie, kompozycja typograficzna oraz tekst na naszych egzemplarza nie są w pełni czytelne. Odczytać można tylko najwyższą linijkę: „BIBLIOTEKA POLSKA”, w następnej linijce, na ile można ją odczytać, widoczny jest adres paryskiej biblioteki: z lewej strony - nazwa miasta („w Paryżu”), a dalej prawdopodobnie nazwa ulicy $(,,[\ldots]$ ORLÉANS[...]").

Jak widzimy, wyodrębnione na podstawie szczególnych cech zewnętrznych, nawet całkiem niewielkie kolekcje związanych z Polską książek charakteryzują się znakomitą różnorodnością autorów i dzieł. Przeglądowy charakter artykułu, niestety, nie pozwala przeanalizować składu innych liczniejszych kolekcji w pełnej objętości. $Z$ tego powodu ich ogólną charakterystykę ograniczymy do wyliczenia tylko pewnej części polskich i obcych nazwisk odnoszących się do tych zabytków. Krąg tych osób jest ważny również z tego powodu, że te nazwiska organicznie dopełniają listę wybitnych średniowiecznych twórców, których dzieła reprezentują w zbiorach GPNTB SO RAN myśl naukową Europy od wieku XV do początków XIX w.

Tematykę Polski i Polaków w zbiorach Oddziału Książki Rzadkiej i Rękopisów reprezentują m.in.: polski historyk i dostojnik kościelny, zasłużony dla odrodzenia katolicyzmu w Polsce - Marcin Kromer (1512-1589); włoski jezuita, pisarz, jeden $\mathrm{z}$ najsubtelniejszych dyplomatów drugiej połowy XVI w., znawca kwestii wschodnioeuropejskich, który próbował Iwana IV (Groźnego) pozyskać dla unii z katolicyzmem - Antonio Possevino (1534-1611); uczestnik synodu w Brześciu w 1596, polski pisarz i dyplomata arcybiskup lwowski Jan Dymitr Solikowski (1539-1603); ksiądz i poeta polski Stanisław Grochowski (1540-1612); hetman wielki koronny, założyciel Akademii Zamoyskiej - Jan Zamoyski (1542-1605); historyk, teolog, polityk, jeden z pierwszych historyków literatury polskiej Szymon Starowolski (1588-1656); teolog polski i niemiecki Jan Krell (1590-1633); teolog Jonasz Szlichtyng (1592-1661); znany polityk i żołnierz, kasztelan krakowski, ojciec przyszłego króla, autor Pamiętnika bitwy chocimskiej Jakub Sobieski (1590-1646); burmistrz Lwowa i pamiętnikarz Kazimierz Kuszewicz (1607-1666); Otto von Guericke - niemiecki matematyk i fizyk, autor pierwszego opisu pompy powietrznej i szkicu do ryciny Gaspara Schotta (1608-1666) „Magdeburskie półkule”, przedstawiającej słynny eksperyment uczonego; przeor klasztoru jasnogórskiego w Częstochowie, organizator bohaterskiej obrony klasztoru w czasie najazdu szwedzkiego 1655 r., który opisał dzieje oblężenia w książce Nowa gigantomachia, opublikowanej w 1658 r. - Klemens August Kordecki (ok. 1605-1673); pisarz, 
historyk, lekarz królewski, pedagog i poeta, którego główne dzieło Florus Polonus stanowi pierwszy opracowany popularnie podręcznik do historii Polski - Joachim Pastorius (1611-1681); astronom, konstruktor teleskopów, rajca gdański Jan Heweliusz (1611-1687); włoski fizyk i matematyk, inżynier w armii papieskiej, profesor filozofii uniwersytetu pizańskiego, jeden z dziewięciu florenckich akademików Carlo Rinaldini (1615-1698); historyk, pisarz moralista, polityk i żołnierz, ideolog ,złotej wolności” Andrzej Maksymilian Fredro (1620-1679); pastor luterański, autor prac z zakresu teologii, nauk przyrodniczych, podręczników itp. - Jan Herbinus (1627-1679); znany polski poeta i historyk, oficjalny nadworny historiograf króla Jana Sobieskiego - Wespazjan Kochowski (1633-1700). Dzieła wymienionych i kilku niewymienionych autorów wypełniają dwie najliczniejsze, umownie wydzielone kolekcje polskiego pochodzenia - Tyzenhauzów i Kosseckich.

Szereg woluminów z kolekcji europejskich książek od XV do początków XIX w. należących do Oddziału Książki Rzadkiej i Rękopisów posiada drukowany ekslibris $\mathrm{w}$ formie pionowej prostokatnej ozdobnej ramki, w środku górnej części której umieszczona jest tarcza herbowa $\mathrm{z}$ wizerunkiem bawołu (rozmiary: papierowy prostokąt z ekslibrisem $-93 \times 68$, sam ekslibris mierzony w skrajnych zewnętrznych punktach $-90 \times 57$, wewnętrzne pole ekslibrisu, ograniczone prostokatna ramka, zamyka-

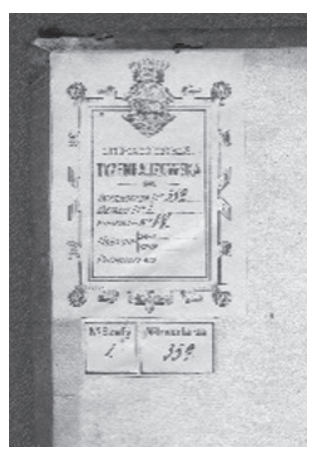
jąca - oprócz nazwy biblioteki - jeszcze inny tekst o charakterze pomocniczym $-58 \times 39 \mathrm{~mm}$ ). Na wewnętrznym polu ekslibrisu, tuż pod tarczą, umieszczono nazwę biblioteki: „BIBLIOTEKA \|| TYZENHAUZOWSKA", jest ona oddzielona od następującego dalej tekstu poziomą kreską z ozdobą typograficzną pośrodku. Zazwyczaj poniżej ekslibrisu, znajduje się naklejka (także drukowana) z dwiema rubrykami: „№ Szafy” $(17 \times 19 \mathrm{~mm})$ $\mathrm{i}$,№ Inwentarza" $(17 \times 26 \mathrm{~mm})$.

Wnioskując na podstawie nazwy kolekcji, mamy prawo sądzić, iż pochodzenie księgozbioru związane jest z osobą Antoniego Tyzenhauza (1733-1785) lub jego kuzyna Konstantego Tyzenhauza (1786-1853). Pierwszy w młodości był bliskim przyjacielem ostatniego króla polskiego i wielkiego księcia litewskiego Stanisława Augusta Poniatowskiego (1732-1798), w późniejszych latach podskarbim litewskim i jednym z najbardziej utalentowanych finansistów swoich czasów. Drugi był szeroko znanym uczonym ornitologiem, który prawie całe swoje życie przeżył w Postawach na terytorium dzisiejszej Białorusi. 
Duże znaczenie dla odtworzenia historii biblioteki Tyzenhauzów, jak sądzimy, mają rękopiśmienne zapiski wykonane ciemnobrązowym żelazistym atramentem $\mathrm{w}$ postaci cyfr umieszczonych $\mathrm{w}$ pierwszych trzech linijkach ekslibrisów. Charakterystyczne, że numer każdej książki, umieszczony w polu ekslibrisu zatytułowanym: „Inwentarza № _” (są to następujące numery: $32,48,133,171,186,187,189,203$ (2 tomy), 204, 209, 210, 234, 235, 237, 239, 264, 276, 289, 322 (2 tomy), 333, 337, 350 (2 tomy), 352, 359, 687 (2 tomy), 697, 735) jest powtórzony później w drugiej rubryce poniższej naklejki. W podobny sposób schodzą się rękopiśmienne numery drugiej linijki ekslibrisu (,Działu № _”) i pierwszej rubryki naklejki (,№ Szafy”). Zapisane atramentem cyfry widoczne w trzeciej linijce ekslibrisu („Podziału № _”) nie są powtarzane na naklejkach. Trzy ostatnie linijki ekslibrisu (,Nabycia \{data _ / cena || Pochodzenie _") żadnych zapisów nie posiadają. Ekslibris zazwyczaj znajduje się na odwrocie przedniej okładziny, w lewym górnym rogu, maksymalnie blisko brzegu. W rzadkich przypadkach jest on umieszczony na wyklejce przedniej okładziny.

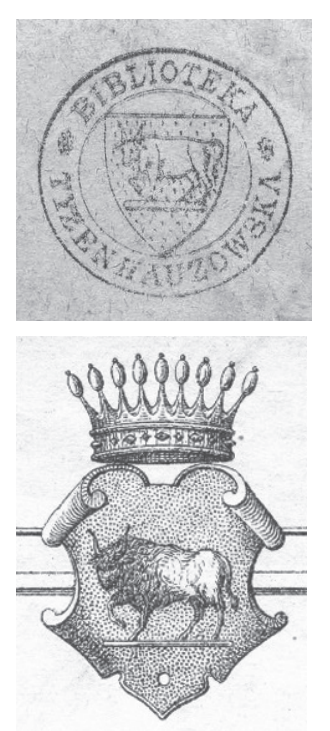

Przechowywane w GPNTB SO RAN woluminy $\mathrm{z}$ tego księgozbioru oprócz ekslibrisu posiadają także pieczęć z tekstem: ,[floratura] BIBLIOTEKA [floratura] || TYZENHAUZOWSKA" (kolor fioletowy; średnica zewnętrzna - 30, a wewnętrzna $-2 \mathrm{~mm})$. W centrum pieczęci znajduję się tarcza herbowa $\mathrm{z}$ wizerunkiem bawołu. Tarcza ma formę trójkąta skierowanego ostrym kątem w dół. Style w których wykonane są wizerunki herbów na pieczęci i ekslibrisie, są różne, uwarunkowane stylem znaku własnościowego, w którym zostały użyte.

Wizerunek bawołu na pieczęci jest podobny do użytego na ekslibrisie. W obu przypadkach zwierzę przedstawiono jako stojące na trzech nogach na cienkiej poziomej podstawie, prawa przednia noga jest uniesiona w półzgięciu.

Trzeba podkreślić, iż bibliotekę Tyzenhauzów wyróżnia charakterystyczna kolejność umieszczania pieczęci na stronach bloku książki. Z zasady odbita jest na karcie tytułowej (wyjattkowo na jej odwrocie) oraz na ostatniej stronie książki. Ten porządek dotyczy zarówno jednostek samodzielnych, jak i dzieł współoprawnych. Ze wszystkich kart tytułowych w dowolnym klocku introligatorskim właściciel oznaczył stemplem tylko pierwszą. Tak samo pieczęć widnieje tylko na ostatniej stronie ostatniego 
dzieła, pozostałe jednostki wydawnicze, które zostały razem oprawione, stempli nie posiadaja.

Osobliwe jest to, że w niewielkiej polskiej kolekcji Oddziału Książki Rzadkiej i Rękopisów, spotyka się także inne warianty tej pieczęci: [floratura] RAINOLD TYZENHAUZ [floratura] \| 1830 i [floratura] RAINOLD TYZENHAUZ [floratura] |1831:

Oba warianty powtarzają podobny typ fioletowego odbicia pieczęci, oba są też okrągłe, tekst umieszczony jest pomiędzy dwoma okręgami, w centrum każdej jest tarcza herbowa $\mathrm{z}$ wizerunkiem bawołu. Różnicą jest kolor (pieczątki 1830 i 1831 są koloru bladoniebieskiego), rozmiar (średnica zewnętrzna $25 \mathrm{~mm}$, wewnętrzna $16 \mathrm{~mm}$ )

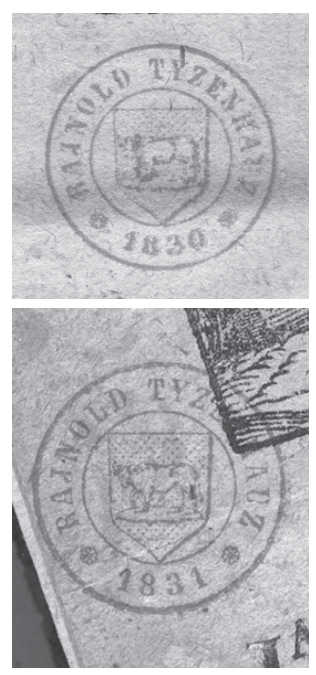
i pewna modyfikacja tarczy herbowej (górna część tarczy zbliża się do kwadratu, dolna jest trójkątna). Proporcjonalnie do rozmiaru całości pieczęci również godło herbowe różni się rozmiarem. Pieczęć z 1830 lub 1831 r. na książkach naszej kolekcji spotykamy tylko w pojedynczych przypadkach.

Pieczęcią z roku 1830 oznaczona jest książka Hymny Koscielne z Brewiarzá Rzymskiego. Pawet S do Efesów w. 5. Nápetnieni badźcie Duchem Swietym, rozmáwiáiac sobie w Psalmiech, Hymnách y pieśniách duchownych: śpiewáią, y chwáte czyniąc $w$ w sercách wászych Pánu [brak miejsca i roku wydania] księdza i poety epoki manieryzmu Stanisława Grochowskiego (1540-1612), natomiast pieczęcią z roku 1831 Ziemianska generalna oekonomika obszernieyszym od przeszłey edycyey stylem svpplementowana $i$ we wszytkich punktách znacznie poprawiona [...] punktami partykularnemi, interrogatoriami gospodarskiemi, praktyka miesięczna, modeliuszami albo tabułami y frakcyami arythmetycznemi obiasniona [...], Cracoviae, typis Vniversitatis, anno Dñi M. DC. LXXIX [1679] napisana przez Jakuba Kazimierza Haura (1632-1709), ekonomistę i autora prac poświęconych rolnictwu.

Obraz kolekcji polskich druków wśród cymeliów GPNTB SO RAN byłby niepełny, gdyby nie wspomnieć o skromnej czarnej pieczątce: ,z BIBLIOTEKI || XAWEREGO \| KOSSECKIEGO” (13×19 mm). Znajduje się ona zazwyczaj na kartach tytułowych książek, niekiedy na odwrocie.

Zazwyczaj towarzyszy jej napis wykonany brązowym żelazistym atramentem: „Ex Bibliotheca Xaverii Kossecki”. Zapis ten występuje w różnych wariantach. Słowo „Bibliotheca” oraz imię właściciela księ- 

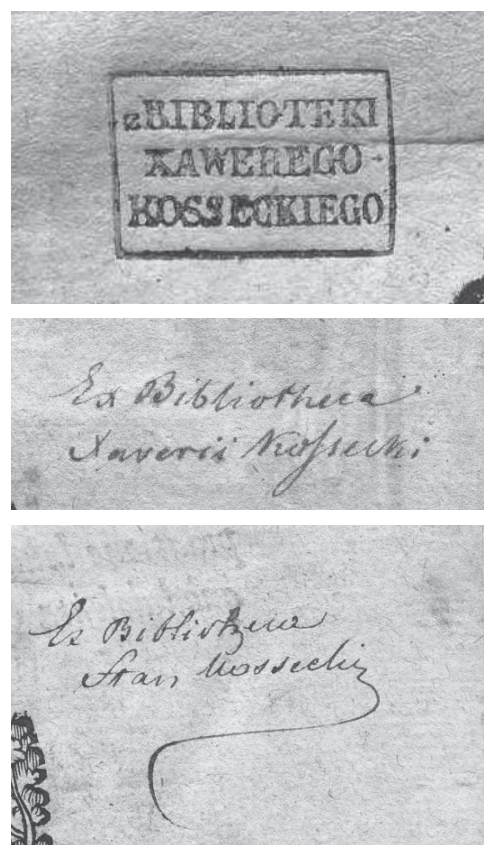

gozbioru dość często są skracane do 3-4 liter, a niekiedy nawet do samego inicjału „X.”. W szeregu przypadków w tekście zamiast Ksawerego wymieniony jest Stanisław: „Ex Bibliotheca Stan. Kossecki”. Nazwisko obu właścicieli spotyka się także w wariancie odcisku pieczęci - „Kosseckiego”.

Niekiedy, w przypadku braku pieczęci ,z BIBLIOTEKI || XAWEREGO \| KOSSECKIEGO”, przynależność książek do tego księgozbioru ustalić można po obecności tylko jednego znaku, czyli napisu z imieniem Ksawerego lub Stanisława. W odróżnieniu od pieczęci napis znaleźć można nie tylko na karcie tytułowej (lub niekiedy na jej odwrocie), lecz także na ostatniej stronie tekstu. Taki sposób umieszczenia napisów własnościowych Ksawerego lub Stanisława Kosseckich przypomina sposób umieszczania stempla biblioteki Tyzenhauzów. Zauważmy, że znaki własnościowe Tyzenhauzów i Kosseckich nierzadko spotykamy na tych samych egzemplarzach, co najprawdopodobniej świadczy o dziedziczeniu albo całego księgozbioru, albo jakiejś jego istotnej części.

Trzeba powiedzieć, że imię Stanisława Kosseckiego jest istotne nie tylko w kontekście biblioteki Tyzenhauzów. Jest ważne również
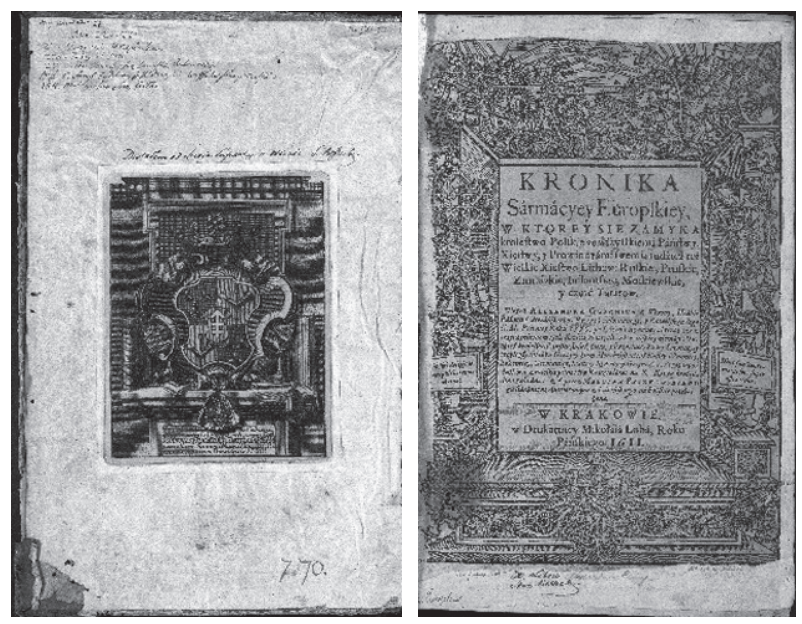
dla księgozbioru wspomnianego wyżej Jana Fryderyka Sapiehy. Jedyny wolumin w naszych zbiorach z ekslibrisem J. F. Sapiehy oznaczony jest równocześnie aż dwoma własnoręcznymi (?) zapisami Stanisława Kosseckiego, przy czym jeden $\mathrm{z}$ nich zawiera bardzo waż- 


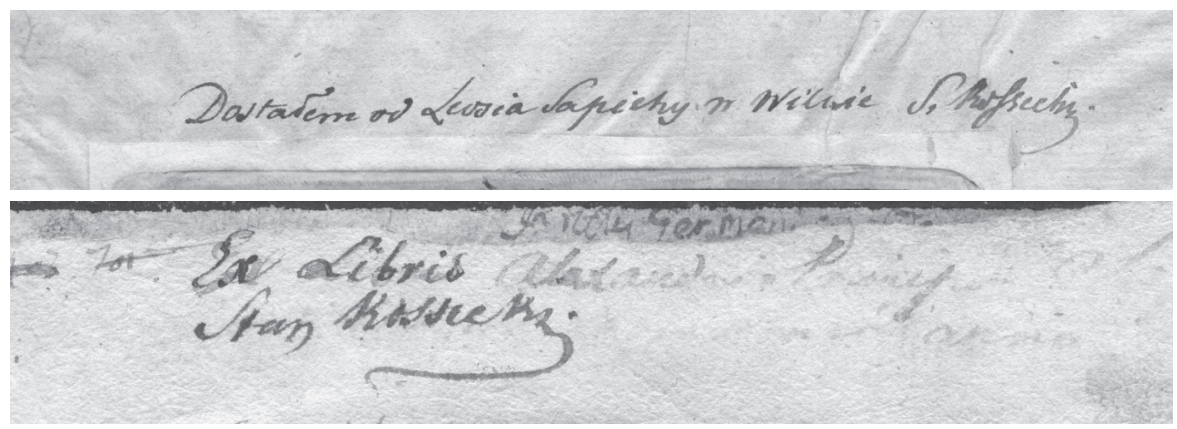

ne z punktu widzenia proweniencji egzemplarza informacje - o otrzymaniu woluminu przez Stanisława Kosseckiego od Leona Sapiehy w Wilnie.

Sądzimy, że historia syberyjskiego egzemplarza Kroniki Sarmacyey Europskiey Aleksandra Gwagnina nie została wyczerpana przez odnalezienie jednego tylko ogniwa łańcucha Sapieha - Kossecki. Drugi napis, z imieniem Stanisława Kosseckiego, widoczny na karcie tytułowej, co można dostrzec przy bliższym przyjrzeniu się, zrobiony został na innym, starszym papierze, co być może wskazuje na nieznanego nam wcześniejszego właściciela książki.

$\mathrm{Na}$ zakończenie chcielibyśmy zwrócić uwagę na oprawy trzech książek jako na szczególnego rodzaju znak własnościowy. Oprawy wykonane są z kartonu obciagniętego pergaminem,
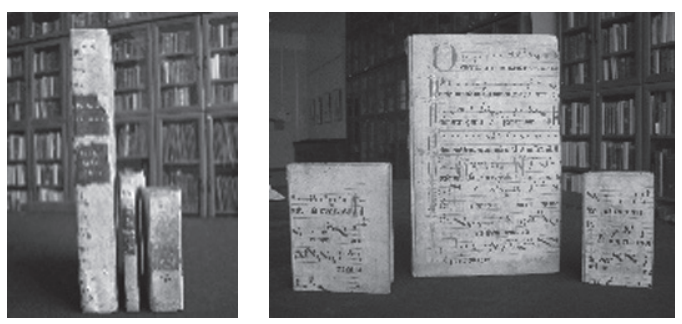
na którym widoczny jest rękopis muzyczny z rzymską notacją kwadratową lub chorałową, uzupełniony tekstem wykonanym pismem gotyckim, czarnym atramentem oraz bogato zdobionymi inicjałami koloru czerwonego i niebieskiego, a w jednym przypadku - z użyciem złota.

Grzbiety opraw wszystkich trzech wydawnictw charakteryzuja się obecnością dwóch szyldzików wykonanych ze skóry - górny w kolorze czerwonym lub żółtym, dolny - ciemnobrązowym, na których złotym tłoczeniem umieszczono tytulaturę dzieł trzech wybitnych Polaków.

Te unikalne w zbiorach europejskich starych druków GPNTB oprawy chronią wydania prac wspomnianego wyżej księdza i poety Stanisława Grochowskiego (Hymny Koscielne z Brewiarzá Rzymskiego...), wybitnego tłumacza z czasów odrodzenia Piotra Kochanowskiego (1566- 
1620) - Torquata Tassa, Goffred abo Jeruzalem wyzwolona... w Krakówie, w druck. Fránciszká Cezárego, 1687 oraz astronoma, konstruktora teleskopów i rajcy gdańskiego Jana Heweliusza (1611-1687) - Prodromus astronomiae... quibus additus est... catalogus stellarum fixarum, tam major ad annum 1660, quam minor ad annum... 1700, accessit... tabula motus Lunae libratorii..., Gedani, typis Johannis-Zachariae Stollii, Anno $M D C X C[1690]$.

Oprócz oprawienia w jednej introligatorni książki te łączy jeszcze szereg cech wydawniczych oraz bibliotecznych polskiego pochodzenia. Prace Jana Heweliusza i Piotra Kochanowskiego wydane zostały w polskich miastach - Gdańsku i Krakowie (w dziele Stanisława Grochowskiego brak adresu wydawniczego). Książa Jana Heweliusza ma ekslibris i dwie pieczątki „BIBLIOTEKA || TYZENHAUZOWSKA”. Wydanie Stanisława Grochowskiego oznaczone jest dwiema pieczątkami «[floratura] RAINOLD TYZENHAUZ [floratura] || 1830» (na karcie tytułowej i ostatniej stronie tekstu), jedna pieczatką, ,z BIBLIOTEKI \| XAWEREGO || KOSSECKIEGO” odbitą na tytule (odbicie jest nieczytelne), z napisem mówiącym o przynależności egzemplarza do księgozbioru Ksawerego Kosseckiego. Karta tytułowa dzieła Piotra Kochanowskiego także posiada napis wskazujaccy na pochodzenie tego rzadkiego egzemplarza z biblioteki Ksawerego Kosseckiego.

Tak w najbardziej ogólnym zarysie przedstawiają się książki polskiego pochodzenia przechowywane w GPNTB SO RAN. W tym ogólnym przeglądzie zasygnalizowaliśmy tylko tematy, które niewatpliwie wymagają pogłębionych i wieloaspektowych badań, a przede wszystkim pełnego naukowego opisu wszystkich egzemplarzy, ze ścisłym wykazem i lokalizacją znaków własnościowych i innych cech każdego wydania. Sądzimy, że taka praca może mieć wielkie znaczenie dla niektórych kwestii związanych z polską bibliografią narodowa, rekonstrukcji dawnych polskich księgozbiorów i historii książki w ogólności.

tłum. Zbigniew Olczak 


\section{Streszczenie}

\section{Polonica w kolekcji ksiazżek europejskich syberyjskiej biblioteki akademickiej}

Stare druki polskiego pochodzenia stanowią jedne z najciekawszych zabytków należących do zbioru europejskich książek XV-XX w. Oddziału Książki Rzadkiej i Rękopisów GPNTB SO RAN. Nie tworzą w nich wydzielonego zasobu i znajdują się tylko w dwóch kolekcjach Oddziału - zbiorach Tobolskiego Seminarium Duchownego oraz europejskich wydawnictw naukowych. Wszystkie bez wyjątku są niezwykle interesujące - zarówno z punktu widzenia ich tematyki, jak i autorstwa, wiadomości o wydawnictwach i proweniencji.

$\mathrm{W}$ artykule poglądowo zaprezentowano obce zasoby Oddziału, gdyż stanowią one kontekst, w którym funkcjonują na Syberii, już prawie od pół wieku, książki od XVI do XIX w. związane z historią Polski. Również poglądowo przedstawione zostały cymelia wydane po polsku lub w Polsce, dotyczace Polski i Polaków oraz rzadkie egzemplarze pochodzące $\mathrm{z}$ dawnych polskich bibliotek, które na skutek różnych wydarzeń znalazły się na Syberii. Studiowanie historii księgozbiorów, rekonstruowanej na podstawie zachowanych na egzemplarzach ekslibrisów, pieczątek, naklejek, charakterystycznych opraw itd., pozwoliło stwierdzić, że niektóre znaki własnościowe występują wielokrotnie. To z kolei pozwala na traktowanie tych przypadków jako większych lub mniejszych umownie wydzielonych kolekcji polskich książek w zbiorach Oddziału Książki Rzadkiej i Rękopisów GPNTB SO RAN.

Słowa kluczowe: stare druki - historia księgozbiorów - polska książa w Rosji.

Summary

\section{Polonica in the European Book Collection of the Syberian academic library}

Old prints of Polish provenance belong to the more interesting materials of the European Book Collection $\left(15^{\text {th }}-20^{\text {th }} \mathrm{c}\right.$.) of the Division of Rare Books and Manuscripts of the State Public Scientific Technological Library of the Siberian Branch of the Russian Academy of Sciences in Novosibirsk (Госуда́рственная публи́чная науччно-техни́ческая библиоте́ка Сиби́рского отделе́ния Российской акаде́мии нау́к). These books do not form a separate organisational unit. They remain dispersed among the two basic collections of the Division: the Tobolsk Seminary and the European Scientific Publications. All these books, 
without exception, are very interesting, from the point of view of their contents, authorship, publication details, and provenance.

The article presents a summary overview of all the foreign collections of the Division, because they form the context in which the Polish books, dated from the $16^{\text {th }}$ to the $19^{\text {th }} \mathrm{c}$., function in Siberia for over 50 years now. This is followed by a description of the books published in Polish, or in Poland, and some rare copies of books formerly kept in Polish libraries, which later on found their way to Siberia. Studies into the history of book collections, reconstructed on the basis of various provenance marks on the copies (bookplates, stamps, stickers, characteristic bookbindings, etc.), revealed the existence of provenance marks, which appear many times, and so allowed for distinguishing various subcollections of Polish books in the holdings of the Division.

Key words: early modern printed books - history of book collections - Polish book in Russia. 